\title{
Responsibility to Protect: Fra folkeret til politisk værktøj
}

Doktrinen om 'Responsibility to Protect' udsprang af debatten om såkaldt humanitær intervention, der især i 1990'erne stod højt på den politologiske og folkeretlige dagsorden. Den grundlæggende idé var at opfinde en ny norm, der foreskrev, at enhver stat har et ansvar for at beskytte sin egen befolkning mod masseforbrydelser, og at det internationale samfund overtager ansvaret, hvis staten enten mangler evnen eller viljen til at leve op til sit ansvar. Dermed vendte doktrinen problemstillingen med humanitære interventioner på hovedet, idet det ikke længere var et spørgsmål om, hvornår det internationale samfund har en ret til at gribe ind og forhindre overgreb på civile, men derimod snarere hvornår det havde et ansvar for at gøre det.

Det er ikke for meget sagt, at 'Responsbility to Protect' - eller blot 'R2P' - er ble- vet et af de nyeste buzzwords i international politik. Det gælder ikke mindst i Danmark, hvor doktrinen bl.a. genfindes i den nu forhenværende Thorning-regerings regeringsgrundlag fra $2011 \mathrm{i}$ henhold til hvilket regeringen vil tilstræbe at 'operationalisere R2P-princippet'.

Også i stater som USA, Storbritannien, Tyskland og Norge har R2P fundet vej ind i centrale officielle udenrigspolitiske dokumenter. Danske og udenlandske politikere og kommentatorer har endvidere henvist til doktrinen som led i deres argumentation til støtte for militære interventioner, der har til formål at komme en nødlidende civilbefolkning til undsætning. R2P-doktrinen blev bl.a. bragt til torvs i forbindelse med den NATO-ledede operation i Libyen i 2011, der havde som sit (officielle) FN-sanktionerede formål at beskytte den libyske civilbefolkning, der var under angreb af Gaddafis fremrykkende regeringssoldater.

Anders Henriksen, Ph.d. er lektor og centerleder for Centre for International Law and Justice, Københavns Universitet. Hans primære forskningsområder er Folkeret - med særlig fokus på reguleringen af staters internationale magtanvendelse [jus ad bellum] og reguleringen af væbnede konflikter (jus in bello]; regulering af terrorbekæmpelse samt menneskerettigheder og deres anvendelse under væbnede konflikter. Han har skrevet en lang række artikler og kronikker. 
Set med folkeretlige briller kan den megen hype, der omgærder doktrinen om R2P, imidlertid undre. For selvom det er korrekt, at R2P i sin tidlige og oprindelige form var et modigt og potentielt set revolutionært forsøg på at ændre de internationale spilleregler for, hvornår stater kan bruge magt mod hinanden i bestræbelserne på at beskytte civile mod overgreb, er det nuværende indhold af doktrinen folkeretligt set ikke særskilt interessant og nyskabende.

Doktrinen om 'Responsibility to Protect' udsprang af debatten om såkaldt humanitær intervention, der især i 1990'erne stod højt på den politologiske og folkeretlige dagsorden. I kølvandet på ophøret af den kolde krig i starten af 1990'erne begyndte en række skrøbelige stater i først og fremmest Afrika og på Balkan at falde fra hinanden, og det betød, at mere eller mindre latente etniske spændinger brød ud i lys lue. Ved flere lejligheder kulminerede de etniske spændinger i blodige borgerkrige, der forårsagede massive humanitære lidelser blandt civilbefolkningen.

\section{Fundamental uenighed}

Selvom FN's sikkerhedsråd udviste en hidtil uset grad af handlekraft efter ophøret af den kolde krig, og bl.a. nåede til enighed om at bemyndige magt som reaktion på borgerkrigene i Somalia og Bosnien, var der desværre også flere eksempler på, at rådet var blokeret og derfor ikke kunne autorisere den magt, der kunne være nødvendig for at bringe en eskalerende humanitær krise til ophør.

Mest tydelig var uenigheden i sikkerhedsrådet i forbindelse med de serbiske etniske udrensninger blandt civilbefolkningen i Kosovo-provinsen. Den anspændte situation i sikkerhedsrådet og på Balkan kulminerede i 1999, da NATO valgte at se stort på fraværet af et mandat fra rådet og gennemføre en humanitær intervention i form af luftbombardementer af serbiske mål for at presse den jugoslaviske forbundsregering til at indstille sine overgreb på civilbefolkningen i Kosovo.

Den til tider meget ophedede debat i 1990'erne om bl.a. interventionen i Kosovo afspejlede en fundamental uenighed $\mathrm{i}$ det internationale samfund om, hvorledes FN-pagten bør balancere de lejlighedsvis modsatrettede hensyn til respekt for staternes suverænitet og beskyttelsen af en nødlidende civilbefolkning. For mens interventionen illustrerede, at en række vestlige stater tilsyneladende var villige til rent undtagelsesvist at tillade indgreb i staternes suverænitet i fraværet af et mandat fra FN's sikkerhedsråd, viste debatten også med al tydelighed, at stort set alle andre stater mente, at ethvert indgreb i statens suverænitet kræver et mandat fra sikkerhedsrådet.

Det var derfor også kun vestlige stater, der bakkede op om den humanitære intervention i Kosovo, og kritikken fra magtfulde ikke-vestlige stater som Rusland, Kina og Indien var utvetydig og ikke til at tage fejl af.

De fleste folkeretsjurister var da også mest tilbøjelige til at anerkende, at det var de ikke-vestlige stater, der havde fat i den lange ende i forhold til legaliteten af sådanne humanitære interventioner. FN-pagten blev forhandlet og formuleret i forbindelse med afslutningen på Anden Verdenskrig, og pagtens bestræbelser på at sikre opretholdelsen af international fred og sikkerhed er baseret på vidtgående respekt for netop staternes suverænitet.

Pagten indeholder et generelt forbud mod at gøre brug af international magt, og der kan kun gøres undtagelser i de tilfælde, hvor FN's sikkerhedsråd bemyndiger magt i henhold til proceduren i pag- 
Den grundlæggende idé var at opfinde en ny norm, der foreskrev, at enhver stat har et ansvar for at beskytte sin egen befolkning mod masseforbrydelser, og at det internationale samfund overtager ansvaret, hvis staten enten mangler evnen eller viljen til at leve op til sit.

tens kapitel 7, eller hvor magtanvendelse er forenelig med staternes ret til selvforsvar. Pagten indeholder ikke flere undtagelser til magtforbuddet og det er derfor også svært at se, at humanitære interventioner ikke altid skulle kræve et mandat fra sikkerhedsrådet for at være forenelige med folkeretten.

Det er da også den konklusion, der genfindes i en DUPI-udredning fra 1999 om de politiske og retlige aspekter af humanitær intervention. Her sondres mellem legalitet og legitimitet og det konkluderes, at "gældende folkeret" ikke giver stater "ret til at foretage humanitære interventioner $i$ en anden stat uden at have bemyndigelse fra sikkerhedsrådet", men at der ikke desto mindre er "stærke moralske og politiske argumenter", der "taler til gunst for legitimiteten af humanitær intervention uden sikkerhedsrådets mandat" (min kursivering). (Dansk Udenrigspolitisk Institut, Humanitær Intervention: Retlige og politiske aspekter 1999, DUPI, s. 126 og 128).

Den udprægede opfattelse af, at humanitære interventioner uden FN-mandat var legitime, men altså også i strid med folkeretten, fik dog ikke debatten til at forstumme. Ved indgangen til det nye årtusinde tog FN's Generalsekretær Kofi Annan atter problemstillingen op, da han stillede et retorisk spørgsmål, som ingen tilsyneladende kunne svare fyldestgørende på: “[I] f humanitarian intervention is, indeed, an unacceptable assault on sovereignty, how should we respond to a Rwanda, to a Srebrenica - to gross and systematic violations of human rights that affect every precept of our common humanity?"
Den canadiske regering reagerede ved at etablere en kommission - the International Commission on Intervention and State Sovereignty - der skulle granske spørgsmålet og forsøge at komme frem til et eller flere konstruktive løsningsforslag. Det var denne kommission, der i 2001 udtænkte begrebet om en forpligtelse til at beskytte civile: 'Responsibility to Protect'.

\section{Forpligtelsen til at beskytte}

Den canadiske kommission formulerede en toleddet politik, der dels satte ord på doktrinen og dels identificerede en række konkrete principper, der skulle danne rammen om de konkrete interventioner, der i yderste konsekvens skulle håndhæve respekten for doktrinen. Den grundlæggende idé var at opfinde en ny norm, der foreskrev, at enhver stat har et ansvar for at beskytte sin egen befolkning mod masseforbrydelser, og at det internationale samfund overtager ansvaret, hvis staten enten mangler evnen eller viljen til at leve op til sit.

Doktrinen vendte herved problemstillingen med humanitære interventioner på hovedet i den forstand, at det ikke længere var et spørgsmål om, hvornår det internationale samfund har en ret til at gribe ind og forhindre overgreb på civile, men derimod snarere hvornår det havde et ansvar for at gøre det. Den anden del af politikken bestod af en række konkrete principper, som skulle vejlede det internationale samfund $\mathrm{i}$, hvornår militær intervention er legitim. Et centralt - og særdeles kontroversielt - element heri var, at kommissionen eksplicit åbnede for, at intervention 
kunne ske uden om FN's sikkerhedsråd, hvis sikkerhedsrådet var lammet og ude af stand til at vedtage de fornødne resolutioner.

Debatten om humanitær intervention forsvandt for en stund fra toppen af den sikkerhedspolitiske dagsorden i kølvandet på terrorangrebene i USA den 11. september 2001. Den canadiske kommissions forslag blev imidlertid atter taget op på FN's World Summit-topmøde i 2005, hvor det dog hurtigt stod klart, at der ikke var opbakning til doktrinens mest interessante og reelt eneste nyskabende element: ideen om, at humanitære interventioner skulle kunne finde sted i fraværet af opbakning fra FN's sikkerhedsråd. Polariseringen fra debatten om Kosovo-interventionen var igen synlig, og det var ikke overraskende især magtfulde stater som Kina, Rusland og Indien, der var mest kritiske.

I sin nuværende udformning af doktrinen, som den kommer til udtryk i topmødets sluterklæring, fremgår det derfor eksplicit, at konkret og væbnet håndhævelse af forpligtelsen til at beskytte en civilbefolkning mod overgreb forudsætter at FN's sikkerhedsråd bemyndiger den nødvendige brug af magt. Det fremgår ganske vist af topmødets sluterklæring, at verdenssamfundet er "prepared to take collective action, in a timely and decisive manner", men det fremgår også, at dette skal ske "through the Security Council, in accordance with the Charter, including Chapter VII [...]". (UN Doc. A/60/1, 24. oktober 2005, \$139, andet led). FN’s Generalsekretær understregede da også i en rapport fra 2009 om implementeringen af R2P, at enhver form for håndhævelse af forpligtelsen til at beskytte civile skal ske i overensstemmelse med pagten, og at doktrinen derfor ikke ændrer - men derimod understreger - de forpligtelser til at afstå fra at bruge magt, der fremgår heraf.

Den canadiske kommissions ambitiøse forslag om at åbne for humanitære interventioner i tilfælde af uenighed i sikkerhedsrådet overlevede altså ikke mødet med FN. Det, der var tænkt som en revolutionerende nyskabelse, endte med at gentage det, der allerede var gældende folkeret: At FN's sikkerhedsråd kan bemyndige brug af magt for at forhindre overgreb på civilbefolkninger - hvis dets medlemmer vel at mærke kan blive enige. Det kræver med andre ord heller ikke en kandidatgrad i jura for at kunne konkludere, at doktrinen ikke bemyndiger humanitære interventioner i fraværet af et mandat fra FN's sikkerhedsråd. Og i det omfang, at doktrinen forpligter nogen, så er det alene sikkerhedsrådet.

\section{Fejlagtige henvisninger}

Det er derfor ikke korrekt, når politikere og kommentatorer med jævne mellemrum gør gældende, at R2P-doktrinen på en eller anden måde skulle kunne udgøre et selvstændigt folkeretligt grundlag for at gennemføre humanitære interventioner uden et mandat fra FN's Sikkerhedsråd.

Den påstand blev bl.a. lanceret under optakten til interventionen i Libyen i 2011, der som tidligere berørt dog endte med at blive gennemført med et mandat fra sikkerhedsrådet. Det er i bedste fald et udtryk for dårlig retsanvendelse og ønsketænkning og i værste fald et bevidst forsøg på at manipulere og efterlade et fejlagtigt indtryk af den folkeretlige retstilstand for at sikre en folkelig opbakning til krigsdeltagelse.

Det er i den forbindelse også værd at hæfte sig ved, at der (heldigvis) var længere mellem de 'fejlagtige' henvisninger til R2P-doktrinen i forbindelse med den militære operation mod Assad-regimet i Sy- 
rien, der var på tegnebrættet i efteråret 2013, efter at Assad havde anvendt kemiske våben mod sin egen befolkning i den syriske borgerkrig.

Helt fraværende var henvisningerne dog ikke, og især i Storbritannien var den offentlige debat af en eventuel britisk krigsdeltagelse skæmmet af, at såvel politikere som kommentatorer gav indtryk af, at R2P udgjorde et folkeretligt grundlag for at gennemføre en operation i Syrien uden FN-mandat. Selvom Vesten som bekendt aldrig gjorde alvor af truslerne i 2013 om at indlede en militær operation mod Assad, nåede både den britiske og den danske regering at udarbejde juridiske begrundelser for, hvorfor en eventuel militær operation i Syrien selv i fraværet af en bemyndigelse fra sikkerhedsrådet efter Storbritannien og Danmarks opfattelse ikke ville være uforenelig med folkeretten.

De britiske og danske begrundelser er interessante, fordi de slet ikke nævner R2P-doktrinen, men i stedet alene anvender begrebet humanitær intervention. I sin begrundelse konkluderer den britiske regering, at de betingelser, der efter Storbritanniens opfattelse skal være opfyldt for, at en humanitær intervention er forenelig med folkeretten, alle er opfyldt i forhold til situationen i Syrien. Den britiske begrundelse ligger herved i klar forlængelse af briternes argumenter for den påståede lovlighed af NATO's humanitære intervention i Kosovo i 1999.

Kort tid efter den britiske juridiske begrundelse for en eventuel forestående militær operation i Syrien blev offentliggjort fulgte den danske regering trop med et juridisk notat om de 'Overordnede principielle overvejelser om det folkeretlige grundlag for en evt. militær operation i Syrien' (Udenrigspolitisk nævn, bilag 298, alm.del, 2012-2013). Den danske begrun- delse minder meget om den britiske, og også her henvises der til en doktrin om humanitær intervention, ligesom der opstilles en række kriterier for sådanne interventioners påståede lovlighed.

Mens Storbritannien som nævnt allerede i forbindelse med Kosovo-interventionen i 1999 anlagde det - kontroversielle - standpunkt, at humanitære interventioner uden FN-mandat kan være forenelige med folkeretten, var den danske regerings notat fra august 2013 historisk på den måde, at det var første gang, at den danske regering anlagde samme synspunkt. Ud over Danmark og Storbritannien er det så vidt vides kun Belgien, der har argumenteret for, at humanitære interventioner kan være forenelige med folkeretten i fraværet af et mandat fra Sikkerhedsrådet.

\section{Et politisk værktøj}

I betragtning af, at R2P-doktrinen - trods lejlighedsvise påstande om det modsatte - ikke udgør nogen nyskabelse i forhold til de folkeretlige regler for anvendelsen af magt er det på sin vis en smule paradoksalt, at doktrinen tilsyneladende lever videre i bedste velgående. Som berørt indledningsvis er R2P langt fra forsvundet ud af politikernes og diplomaternes talepapirer, og der refereres fortsat hyppigt til doktrinen og behovet for, at dets principper operationaliseres og føres konkret ud i livet.

R2P's fortsatte 'succes' må først og fremmest tilskrives det forhold, at doktrinen $\mathrm{i}$ løbet af de ti år, der er gået siden FN's World Summit i 2005, ikke længere kun er et mundret samlebegreb for en række allerede eksisterende folkeretlige forpligtelser.

For selv om doktrinen som beskrevet i dette korte bidrag havde sit udspring i den folkeretlige debat om humanitær intervention og det folkeretlige system for re- 
gulering af interstatslig magtanvendelse, handler doktrinen i dag om meget andet end jura. R2P er blevet til et politisk værktøj, der rummer alt fra forebyggende indsatser i ustabile stater, såsom forskellige former for 'early warning-systemer' og identificeringen af 'focal points', til diverse former for kapacitetsopbygning.

Et blik på den skov af dokumenter, erklæringer og resolutioner, der henviser til R2P, viser med al tydelighed, at doktrinen i dag udgør en samlende ramme for bredspektrede bestræbelser på at forebygge konflikter og beskytte civile mod overgreb. Et af de senere skud på R2P-stammen er det såkaldte 'Responsibility while Protecting', der på Brasiliens foranledning bl.a. betoner ansvarsspørgsmål under indsatser for at bistå civile.
Doktrinens fortsatte eksistens vidner om, at det er lykkedes at skabe international konsensus om, at masseforbrydelser og grove overgreb mod civilbefolkninger utvivlsomt er noget, der kalder på en samlet og fælles reaktion fra det internationale samfunds side. Selvom der kan være uenighed om midlerne, er der dog enighed om målet. Denne udvikling er imidlertid ikke uden risici. For i takt med at R2P skal indfange stadigt flere indsatsområder og politikker forøges risikoen for, at dets normative status bliver tilsvarende diffus og mudret og dets evne til at normere svækkes yderligere.

Jo flere ting, der inkluderes i doktrinen, jo mindre forpligtende kan den opfattes. 